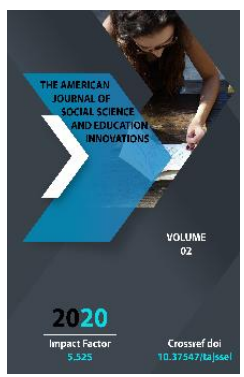

\title{
The Problem Of Comparative Study Of Samples Of World Literature In General Secondary Schools
}

\author{
Nurjan Buranovich Abduvalitov \\ Independent Researcher TSPU Named After Nizami Uzbekistan, Tashkent,
}

Copyright: Original content from this work may be used under the terms of the creative commons attributes 4.0 licence.

\section{ABSTRACT}

This article deals with the issue of comparative study of the works of Russian writer A. Chekhov and Uzbek writer A. Qahhor from the examples of world literature.

\section{KEYWORDS}

Comparative analysis, creative laboratory, biographical method, author's language, writing skills, methodological direction.

\section{INTRODUCTION}

The study of the interrelationship of Uzbek and world literature is an effective tool that motivates students to get acquainted with world culture. This, in turn, helps students become aware of information that is both national and universal in nature. In our opinion, the study of the characteristics of the creative laboratory of different writers as a whole can also be included in the object of comparison. From this point of view, the comparative study of the works of the Russian writer A.Chekhov and Abdulla Qahhor allows to examine in one aspect the peculiarities of the language, skill, direction, stylistic individuality of these two writers. 


\section{THE MAIN RESULTS AND FINDINGS}

It is known that A. Chekhov is a sharp penman who has gained great skill in storytelling. In the author's stories, real-life events are artistically embodied in short and humorous language. His heroes are also ordinary people. Such qualities are also evident in the works of the Uzbek writer A. Qahhor. The ability to type every word, to absorb the subtle meaning in a concise way is a vivid expression of heroic jewelry.

In the 11th grade of secondary schools in the study of the author's story "Hostage" by analyzing the peculiarities of the author in the framework of the biographical method, A. Qahhor and Chekhov are able to compare the nature and style. "The biographical method is a method of research in literature that considers and interprets the biography and life experience of a writer as a decisive factor in the creation of his works. Of course, the writer seeks to shed light on topics that are familiar to him, to draw public attention to issues that have shaken his heart. At the same time, it is a fact that personal experience and life experiences do a great job and do not require discussion. However, it is illogical to idealize the role of biography in the analysis of a work, to try to find something about the personality and biography of the writer in the study of each work [1]".

The commonalities in Chekhov's and Qahhor's work are initially felt in the fact that they are able to add great meaning to a small volume in their works. Observing the way of life of ordinary people, sharing people's sorrows, deep study of the social life of their time and human relations, the ability to transfer the flaws of society is the product of deep gaze to the images of heroes with light or bitter laughter A.Chekhov and A.Qahhor artistic and critical thinking.

There are elements of literary influence in AP Chekhov's story "Vanka" in which the boy begs his grandfather to take him home, unable to bear the tyranny of the shoemaker A. Qahhor's request to the mother of the girl in the story "Sick" for healing. Giving students an understanding of interactions in the study of a writer's biography also requires the use of ideas that the authors themselves have acknowledged.

Materials with such content further brighten students' perceptions of the topic:

"Qahhor writes: "My childhood was spent in the Fergana Valley... When I remember the mid-thirties, it seemed like a messy and strange dream to me... I had many such memories. They often leaked to the surface, but there were also those that would remain in the deep memories of my mind. Thirty years ago I received a collection of twenty-two chapters by Anton Pavlovich Chekhov. I read this book in almost a few days. Something very unusual happened, as if the author of a great story, a respected teacher, had put his spectacles in my hand and said, "Put on your spectacles and look at the past of your people."... Thus, the image of youth awoke in my mind, and the past life became more vivid before my eyes. Probably for this reason, my stories created in the mid-thirties are full of grief: "The Thief", "The Sick", "Nationalists", "City Garden"..." [2].

In the process of comparison, if students 'attention is focused on the author's language, narrative style, protagonist speech, and closeness to selected details, harmony in the course of events becomes apparent. For example, the biography of A. Qahhor in the 7th grade of general secondary schools and by 
acquainting the readers with some episodes of A.Chekhov's story "Curved Mirror" while studying the story "Horror", it can be argued that these two writers are the connecting points..

The following scenes from Chekhov's story are undoubtedly reminiscent of the pathos in harmony with the lines in "Horror":

"And the wind howled. It was as if someone was crying in a stone pipe, and the sounds of despair could be heard in his cry. Huge raindrops hit the tinted windows, which were heartbreaking...

My wife, too, stared out the window in fear, and disaster struck! Her face turned white, her whole body began to tremble, and she suddenly screamed. The candle in his hand fell to the ground and rolled, and the candle went out. We were left in a pitch-dark winter. At that moment, something fell to the ground: my wife had fainted. The wind howled worse than before, inside the house rats began to run, and mice rustled the papers. The curtain of one window was torn and shattered, and my hair stood on end. The moon was shining through the window" [3].

The howling of the wind; raindrops hitting the window; dark winter; the comparison of the image of the curtain falling down and the moon shining through the window to the following scenes in the story "Horror" meets the criteria of the method of comparison:

"The wind howled like a hungry wolf, and howled like a cat caught in the clutches of death, and nothing could be seen.... When the wind blew, it brought something and hit the window. He slipped and fell as the object scratched the window. It was as if an inch had sunk into the seat where everyone was sitting..." [4].

\section{CONCLUSION}

The conclusion is that through a method like the one above, students will witness the creativity of people who have lived in different places and times, reflecting the deep worldview, common sense, and life wisdom of the people to whom they belong. The analyzed objects, in particular, the works of Chekhov and Qahhor, are convinced of the uniqueness of the style, the richness of the language of the works of the various peoples, the richness of the narrations and the absence of extravagance and ornaments.

\section{REFERENCES}

1. http://eadabiyot.uz/adabiyotshunoslik/ata ma/651-atamalar-lugati.html

2. https://arboblar.uz/uzkr/people/kakhkharabdulla

3. https://ziyouz.uz/jahon-nasri/antonchexov/anton-chexov-qiyshiq-oyna-hikoya/

4. Yo'Idoshev Q. va boshq. Adabiyot: Umumiy o'rta ta'lim maktablarining 7-sinfi uchun darslik-majmua. - Toshkent: Sharq, 2017. 317-b.

5. Odilov, B. A., \& Karimov, N. R. (2020). ANALYSIS OF TARGETED RESEARCH IN 2030 YEARS OF THE XX CENTURY. PalArch's Journal of Archaeology of Egypt/Egyptology, 17(6), 8887-8893.

6. Salima Rustamiy. (2020). scientific and theoretical content of the science of balāğat. Journal of Critical Reviews, 7(6), 132-137.

7. Sodirjonov, M. M. (2020). Some Thoughts On The Evolution Of Approaches To The Concept Of Human Capital. The American Journal of Social Science and Education Innovations, 2(08), 144-150. 
The American Journal of Social Science and Education Innovations (ISSN - 2689-100x)

Published: January 10, 2021 | Pages: 44-47

Doi: https://doi.org/10.37547/tajssei/Volume03Issue01-09

8. Carayannis, E. G., Evans, D., \& Hanson, M. (2003). A cross-cultural learning strategy for entrepreneurship education: outline of key concepts and lessons learned from a comparative study of entrepreneurship students in France and the US. Technovation, 23(9), 757-771. 